\title{
Stakeholders' Perception of the Independence of Public Sector Auditors in Nigeria
}

\author{
Oyerogba Ezekiel Oluwagbemiga (Corresponding author) \\ Department of Economics, Accounting and Finance \\ Jomo Kenyatta University of Agriculture and Technology, Kenya \\ Tel: 23-480-6630-8115_E-mail: oyeezekiel2903@yahoo.com
}

Solomon Adeoluwa Zaccheaus

Department of Economics, Accounting and Finance

Jomo Kenyatta University of Agriculture and Technology, Kenya

E-mail: a.zsolomon@yahoo.com

\author{
Olaleye Michael Olugbenga \\ Department of Economics, Accounting and Finance \\ Jomo Kenyatta University of Agriculture and Technology, Kenya \\ E-mail: olaleyeolugbenga@yahoo.com
}

\begin{abstract}
AdesinaTemitopeOluwaseyi
Accountancy Department, Federal Polytechnic, Offa, Kwara State, Nigeria

E-mail: sheyitope@yahoo.com
\end{abstract}

Received: Sep. 22, 2014

doi:10.5296/ajfa.v6i2.6342
Accepted: Nov. 20, $2014 \quad$ Published: December 1, 2014

URL: http://dx.doi.org/10.5296/ ajfa.v6i2.6342

\begin{abstract}
This study is an endeavor to investigate the extent to which public sector audit independence was achieved and how it was achieved in Nigeria. The emphases were on the three significant aspect of independence (investigative independence, reporting independence and financial independence) which were used in formulating the three hypotheses that guided the study. By
\end{abstract}




\section{Macrothink}

means of survey design, the study relied on primary data obtained through a well-structured questionnaire administered to a sample of 96 respondents randomly selected from the population for the study. Employing both descriptive and inferential statistics for the analysis, it was observed that a high level of independence was maintained by the public sector auditors in Nigeria. Similarly, the results of the inferential statistic revealed that there is likelihood of quality audit assignment where investigative independence, reporting independence and financial independence of auditor general is guaranteed. It is therefore appropriate for the legislature to put in place necessary machinery to promote the independence of the auditor general at all level of governance if the objectives of providing transparent and responsible government will be achieved.

Keywords: Audit Independence, Public Sector Organization, Reporting Independence, Investigative Independence, Financial Independence 


\section{Introduction}

\subsection{Background of the study}

Independence has always been considered a crucial attribute of an auditor, external or internal, private or public. The national audit office (UK) public audit manual of 1988 and developed by and for commonwealth nations' auditor generals established certain criteria for promoting the independence of public sector auditors (Auditor General) (Andy, 2001). The criteria among others include that the appointment and dismissal of the auditor general not to be within the prerogative of the executive, the auditor general's salary to be a direct charge on public fund and not subject to annual appropriation, the auditor general's right to report directly to the legislative rather than to and through the executive and to decide the nature and timing of the report, the auditor general to have the power to appoint and pay the staff in line with the civil service condition but subject to budgetary approval by the legislature or a body empowered to so by the legislature, the auditor general to have a right of access to papers and information and to obtain information and explanations, and that the audit mandate should cover all public enterprises (Andy, 2001).

Similar provisions can be found in local regulations such as audit act of 1958, section 24 of the finance (control and management) act of 1958, the fiscal regulation of 1976, the audit standard, civil service rules and section 85(2) of the 1999 constitution of the federal republic of Nigeria (Omolehinwa, 2004). However, it has been recently observed by Galwene, (2008) that this independence that is a panacea to the success of any auditing job is only a theoretical provisions and not being enjoyed by public sector auditors. Oladipupo\&Izedonmi, (2013), stated that for the audit report to be publicly accepted as reflecting the true and fair view the organization position, auditors must be seen to be indeed truly independent. In addition to technical competence, auditor independence appears to be the most important factor in establishing the credibility of the audit opinion (baker, 2005).

Therefore, considering the significant role of audit report in improving the quality of financial statement, this study attempted to investigate the level of independence being enjoyed by the auditors at the three tiers of government in Nigeria (Federal, States and Local Governments) compare to their counterparts in the private sectors.Nigeria democratic system is structured into three tiers with each government holding a separate and distinct account as allocated from the federal treasury and in addition to other revenue derived frominternally generated revenue such as taxes and levies. This in turn, has put a responsibility on the leadership and management of these tiers of government to render a stewardship report to the citizenry who have given them the mandate to manage their resource. However, for these reports to achieve its intended purpose there is a need for the provision of written reasonable assurance from independent sources that the financial statements present a true and fair view in accordance with the accounting standards (Oladipupo\&Izedonmi, 2013).

\subsection{Statement of problem}

Recent corporate scandals and legislation like the Sarbanes-Oxley Act have spurred the public to focus on the importance of governance (Nashuwa, 2005). According to John, (1995) 
governance is not limited to business entities: It is important to public sector entities as well. Public sector entities include state and local governments, federal agencies, public utilities, hospitals, colleges and universities, pension plans, city councils, boards of trustees, legislatures, and boards of governors (Doyle, 2005). Governance in the public sector deserves the same attention as governance in the corporate sector. While unethical behavior in the corporate sector impacts the shareholders of a company, unethical behavior in the public sector impacts all taxpayers and citizens (Muhamad\&Kabhari, 2006). In other words, government programs should be managed in a way which represents value for money for the taxpaying community. However, the recent scandals involving Long Island school districts illustrate all too well that this objective has not been achieved even in the developed societies (Nashuwa, 2005). The government is obliged to account to taxpayers for its management of public funds and services. It must ensure that funds are properly raised, protected from loss, and spent with maximum efficiency and effectiveness for the purposes approved by Parliament (Doyle, 2005). Consequently, for effective functioning of the management, there is a need for independent monitoring in form of auditing. Therefore, U.S. Government Accountability Office (GAO) in 2003, recommend that public sector entities consider the benefit of strengthening the independence of auditor general.

\subsection{Aims and objectives of the study}

Primarily, the study aim at investigating the extent to which public sector audit independence is achieved and how this independence is achieved in the Nigeria public sector organizations. The specific objectives include:

(i) To investigate the extent to which investigative independence is achieved in the public sector organizations.

(ii) To investigate the extent to which reporting independence is achieved in the public sector organizations

(iii) To investigate the extent to which financial independence is achieved in the public sector organizations.

(iv) To determine the effect of investigative independence, reporting independence, financial independence on the quality of audit assignment in the public sector organizations.

\subsection{Significance of the study}

This study contributes to the existing body of knowledge, as well as make up for the paucity of scholarly papers in Nigeria on independence of public sector auditors. Also, the findings of this study will aid an efficient and effective performance of duties by the auditor generals in Nigeria.

Regulatory authorities will also find the study helpful in policy making and implementation. 


\subsection{Research questions}

Supporting the research objectives stated above, the following research questions were raised and will be answered during analysis.

(i) To what extent does public sector auditors enjoyed investigative independence

(ii) To what extent does public sector auditors enjoyed reporting independence

(iii) To what extent does public sector auditors enjoyed financial independence

(iv) To what extent is the audit engagement in the public sector organizations affected by investigative independence, reporting independence and financial independence

\subsection{Research Hypotheses}

The following research hypotheses were formulated in null form for the study in line with the research questions and objectives.

(i) There is no significant relationship between the quality of audit assignment and auditor's investigative independence.

(ii) There is no significant relationship between the quality of audit assignment and auditor's reporting independence.

(iii) There is no significant relationship between the quality of audit assignment and auditor'

\section{Review of Literature.}

\subsection{Theoretical Review.}

Theoretical framework serves as a base for the interpretation of empirical results of a study. The main theory for this study is the performance theory of public sector auditing.

\subsubsection{Performance theory of public sector auditing}

After the beginning of the transitional period to market based economy, the Central and Eastern Europe countries had to re-establish a proper auditing practice as befits a democratic institutional system. The theory for the new institutional framework was based, in the majority of the countries concerned, on the legislation and experience of western democracies. The adoption of performance auditing in the public sector is one of the more significant new additions to the traditional auditing role (financial audit). In a financial (or regularity) audit, the auditor expresses an opinion whether the financial statements are prepared, in all material respects, in accordance with the applicable financial reporting framework. In a performance audit, the auditor expresses an opinion whether, in all material respects, the administration of a particular program or entity has been carried out economically and/or efficiently and/or effectively. Performance auditing is relatively a new type of audit. Performance audit represents according to the INTOSAI international audit standards1, an independent, assessment or examination of the extentto which an activity, program or public institution operates efficiently and effectively, with due regardto economy. As proposed by Adriana, (2007), it is important to understand that in the present days, sufficient condition does not 
mean that the public money are spent according to law provision, but they must be under the economic, efficient and effective condition too. This new type of audit has evolved to meet the need for greater information by the taxpayer and its representative, Parliament, mainly regarding the efficiency and economy in the use of resources by the public managers acting on behalf of the executive. These requirements prompted audit offices to develop their own institutional capabilities and to apply the highest standard auditing procedures and techniques to ensure that decision makers can be assured that the budgetary resources and assets are utilized in an economical and effective way. In addition to that, Demirag and Khadagoo, (2012) stated that the robust objective setting and performance appraisal systems, which are essential prerequisites for a workable performance management system is essential in achieving the objectives of performance audit.

\subsection{Empirical Review}

\subsubsection{The concept of Auditor's Independence}

The initial concept of auditor independence was primarily of British origin, in the 19th century, where auditors doubled as book keepers (Baker, 2005). Aderibigbe (2005) views independence as an emotive word serving as a banner for freedom, integrity and all that is good. Auditor independence according to Dictionary of International Accounting Terms (2001) infers a state of impartiality required of auditors who should have no personal or financial involvement with a client. Louwers et al. (2007) expresses independence as a mental attitude and physical appearance which portrays the auditor as being uninfluenced by others in judgment and decision. This can be sustained by avoiding financial connection that makes it appear that the wealth of the auditor depends on the outcome of the audit and management connections that makes the auditor appear as if he is involved in management decisions. As a key ingredients of audit quality Gray \& Manson (2000) and Hayes et al. (2005) described independence as a position required in other to take an unbiased viewpoint in the performance of audit tests, analysis of results and attestation

in the audit report. Despite all the definitions, and descriptions of auditor independence, Whittington \&Pany (2004) concluded that auditor independence is relative and not absolute. According to Tairu (2009), auditor independence comprises of programming independence, investigation independence, and reporting independence. Of these three components, reporting independence is the most likely to be influenced by the directors of a client company. This is the foci of this research. The independence of auditors is seen as a means and not an end in itself (McGrath,et al., 2001). Consequently, Smith (2003) opined that the prime responsibility of maintaining independence and objectivity rests with the auditor.

\subsubsection{Investigative independence}

Iyawe (1997) viewed investigative independence as protecting the auditor's ability to implement the strategies in whatever manner they consider necessary. Similarly as perceived by Dunn, (1996) auditors must have unlimited access to all client information. In like manner, Baker, (2005), suggests that queries regarding a client's business and accounting treatment 
must be answered by the client. Paul and Walker, (2009) opined that the collection of audit evidence is an essential process, and cannot be restricted in any way by the client company.

\subsubsection{Reporting independence}

Reporting independence was recognized by Iyawe, (1997), as instrument protecting the auditor ability to choose to reveal to the public any information they believe should be disclosed. If company directors have been misleading shareholders by falsifying accounting information, they strive to prevent the auditors from reporting this .It is situation like this that auditor independent in most likely to be compromising like this that auditor independence is most likely to be compound.

\subsubsection{Financial Independence}

It has been observed that the more economically dependent the auditor is on the client, the more likely the auditor is to succumb to client pressure (Nelson, Elliot \&Tarpley, 2002; Trompeter, 1994). Mautz and Sharaf (1961) recognize the auditor's financial dependence on clients as a built-in-anti-independence factor. They further observe that since auditors are financially dependent on the client, their independence as regards the financial reports might be reduced. DeAngelo (1981) argues that future economic interest in a client reduces the auditor's independence towards the client. In other words, the greater the client-specific quasi-rent stream, the less likely the auditor is to report a discovered breach.

\section{Methodology}

\subsection{Research design}

By means of survey research design, this study examined the extent that public sector audit independence is achieved the how this independence is actually achieved in Nigeria. The choice of this design was due to the fact that the research perceived it as being appropriate because of his lack of control over the responses and inability to manipulate sample subject.

\subsection{Population of the study}

The population for this study consisted of the auditor general of the federation and all the staffs in the office of the auditor general of the federation and also the auditor general for the 36 states in Nigeria and all the staffs in their respective offices.

\subsection{Sample and sampling techniques}

The data used for this study were collected from a sample of 105 respondents using a stratified sampling technique and simple random sampling technique. Since the south west region was used as the study location, a state was regarded as a stratum and 15 respondents were randomly selected from the state auditor general office of the six states in the region and the remaining 15 respondents were selected from the office of the auditor general for the federation to arrive at the sample for the study. The adoption of this sampling technique was based on the criteria set by the researchers which include the experience of the respondent, their knowledge on the subject matter, and their reasoning ability. 


\subsection{Research instrument for data collection.}

The data for the study were generated by means of a well-structured questionnaire administered to 105 staff of the selected states and the federal capital territory. The reason for this instrument was that questionnaire is the most widely used instrument for data collection and because it is a quick means of obtaining the views of the respondents on a wide range of subjects.

\subsubsection{Validity of Research Instrument}

To enhance the validity of the research instrument draft copy of the instrument was given to 3 holders of doctor degree in accounting 2 chartered accountants and 2 retired auditor general whose constructive criticisms were taken into consideration to ensure that the questionnaire contained all the relevant dimension of the study.

\subsubsection{Reliability of research instrument.}

Towards assuring the reliability of the instrument, a test and re-test method was used. The aim was to find out how consistent the instrument was in collecting the required data for analysis. The results of reliability analysis revealed a Cronbach Alpha 0.928 for items relating to financial independence, 0.886 for investigative independence and 0.869 for items relating to reporting independence. The psychometric tests suggest the presence of reasonable level of reliability

\subsection{Administration of research instrument.}

One hundred and five (105) copies of the questionnaire were distributed by the researcher with the help of two 2 research assistant to the respondents directly. Ninety six (96) copies of the questionnaire were returned representing $91.4 \%$ of the total copies distributed, while nine (9) copies were not returned due to constraint of time representing $8.6 \%$ of the total copies distributed.

\subsection{Statistical tool/ analytical procedures}

The study adopted both descriptive and inferential statistics for the analysis of data. Descriptive statistic includes the frequency and percentage while the inferential statistic focused on multiple linear regression analysis with the aid of statistical package for social science (SPSS) version 17.0. The general formula for the study model was as follows;

$$
\mathrm{Y}=\beta 0+\beta 1 \mathrm{X} 1+\beta 2 \mathrm{X} 2+\beta 3 \mathrm{X} 3+\mu
$$

Where;

$\mathrm{Y}=$ Auditor Assignment

$\mathrm{X} 1=$ Investigative Independence

$\mathrm{X} 2=$ Reporting Independence

X3= Financial Independence 
In the model, $\beta 0=$ the constant term while the coefficient $\beta \mathrm{ii}=1 \ldots .3$ was used to measure the sensitivity of the dependent variable (Y) to unit change in the predictor variables. $\mu$ is the error term which captures the unexplained variations in the model.

\section{Analysis and interpretation of data}

\subsection{Presentation of Demographic Data}

Tables 1 shows that out of the 96 respondents, fifty eight (58) respond representing $60.4 \%$ were males while the remaining 38 respondents representing 39.6\% were females. This shows that the male respondents were more than the female respondents. It was also revealed that 16 respondents representing $16.7 \%$ had between $1-5$ years working experience, 20 respondents representing $20.8 \%$ of the total had working experience of $6-10$ years, 8 respondents representing $8.3 \%$ had worked for $11-15$ years, 24 respondents $(25 \%)$ possessed between 16-20 years of working experience, while the remaining 28 respondents representing 29.2 of the total had worked for over 20 years in the field. It can therefore be said that majority of the respondents had worked for over 20 years. Furthermore, the results on educational qualification shows that 4 respondents representing $4.2 \%$ possessed an SSCE certificate, 64 respondents, representing $66.6 \%$ of the total possessed BSC / HND qualification, 28 respondents (29.2\%) of the respondents possessed MSC/ MBA degree as their highest academic qualification. This implies that majority of the respondents were BSc./HND holders, meaning that a group of learned and experience staffs in the subject investigated covered were selected for the study. In like manner, it was also observed that 44 respondents $(45.8 \%)$ belonged to the professional membership of ICAN, 12 respondents representing $12.5 \%$ of the total belonged to the professional membership of ANAN while the remaining 40 respondents representing $41.7 \%$ of the total did not belong to any professional institute. This implies that majority of the respondents are professionally qualified for their job.

Table 1. Presentation of demographic data of the respondents

\begin{tabular}{|c|c|c|c|c|c|c|c|c|c|c|}
\hline \multirow[t]{2}{*}{ Gender } & \multicolumn{2}{|l|}{ Male } & \multicolumn{2}{|l|}{ Female } & & & & & & \\
\hline & Frequency & & Frequency & & & & & & & \\
\hline & 58 & 60.4 & 38 & 39.6 & & & & & & \\
\hline \multirow{3}{*}{$\begin{array}{l}\text { Work } \\
\text { Experience }\end{array}$} & \multicolumn{2}{|l|}{$1-5$ years } & \multicolumn{2}{|l|}{$6-10$ years } & \multicolumn{2}{|c|}{$11-15$ years } & \multicolumn{2}{|l|}{$16-20$ years } & \multicolumn{2}{|l|}{$20 \&$ above } \\
\hline & frequency & $\%$ & Frequency & $\%$ & frequency & $\%$ & Frequency & $\%$ & Frequency & $\%$ \\
\hline & 16 & 16.7 & 20 & 20.8 & 8 & 8.3 & 24 & 25 & 28 & 29.2 \\
\hline \multirow[t]{3}{*}{ Educ. Qual. } & \multicolumn{2}{|l|}{ SSCE } & \multicolumn{2}{|l|}{ BSc./HND } & \multicolumn{2}{|c|}{ MSC./MBA } & & & & \\
\hline & frequency & $\%$ & Frequency & $\%$ & frequency & $\%$ & & & & \\
\hline & 4 & 4.2 & 64 & 66.6 & 28 & 29.2 & & & & \\
\hline \multirow[t]{3}{*}{ Prof. Qual. } & \multicolumn{2}{|l|}{ ICAN } & \multicolumn{2}{|l|}{ ANAN } & \multicolumn{2}{|l|}{ Others } & & & & \\
\hline & frequency & $\%$ & Frequency & $\%$ & frequency & $\%$ & & & & \\
\hline & 44 & 45.8 & 12 & 12.5 & 40 & 41.7 & & & & \\
\hline
\end{tabular}




\subsection{Presentation and Analysis of Data According to Research Questions}

4.2.1 The Extent to Which Investigative Independence is Achieved in the Public Sector Organizations.

Information for this analysis was from the responses obtained from the respondents. For the above stated objective, five (4) questionnaire items were put forward to the respondents, the responses obtain were captured in table 2.

In the Nigeria public sector, investigative independence could be said to have been achieved to a reasonable level based on the opinion of the randomly selected 96 staff of the auditor general office. First, it was observed that the auditor general either at the state level or the federal level was able to determine the scope of the audit work to be carried out on the financial statement prepared by the accountant general office without any hindrance from any constituted authority. This was supported by the $78 \%$ respondents strongly agreed and agreed to the question on the extent to which auditor general was able to determine the scope of audit work in the public sector organizations. Secondly, the removal of auditor general was done by the legislature and through a two third majority. Infact, the result of the interview conducted revealed that before the last military government, all auditor generals in Nigeria had either retired voluntarily or on reaching the retirement age. Furthermore, the compliance level for the submission of annual financial statement by the office of the accountant general to the auditor general office was also commendable. Although, there were cases of failure in meeting the deadline as stipulated by the regulation but annual financial statement audit was done in all the state sampled. However, there is the need for improvement on the willingness of the executive to give out relevant and appropriate information to aid an effective audit work in the public sector as only $38 \%$ of the respondents agreed and strongly agreed that auditor general was able to request information considered necessary for the discharge of his duty from the executive. 


\section{Macrothink}

Asian Journal of Finance \& Accounting ISSN 1946-052X 2014, Vol. 6, No. 2

Table 2. The extent to which investigative independence was achieved in the public sector organizations

\begin{tabular}{|c|c|c|c|c|c|c|c|c|c|c|c|c|}
\hline & \multicolumn{2}{|l|}{$\begin{array}{l}\text { Strongly } \\
\text { Agreed }\end{array}$} & \multicolumn{2}{|l|}{ Agreed } & \multicolumn{2}{|l|}{ Indifferent } & \multicolumn{2}{|l|}{ Disagreed } & \multicolumn{2}{|l|}{$\begin{array}{l}\text { Strongly } \\
\text { Disagreed }\end{array}$} & \multicolumn{2}{|l|}{ Total } \\
\hline & Frequency & $\%$ & Frequency & $\%$ & Frequency & $\%$ & Frequency & $\%$ & Frequency & $\%$ & Frequency & $\%$ \\
\hline $\begin{array}{l}\text { Auditor } \\
\text { general was } \\
\text { able to } \\
\text { examine the } \\
\text { financial } \\
\text { statement } \\
\text { annually }\end{array}$ & 51 & 53 & 24 & 25 & 1 & 1 & 18 & 19 & 2 & 2 & 96 & 100 \\
\hline $\begin{array}{l}\text { Auditor } \\
\text { General } \\
\text { was able to } \\
\text { determine } \\
\text { the scope of } \\
\text { audit work }\end{array}$ & 48 & 50 & 40 & 42 & 4 & 4 & 4 & 4 & - & - & 96 & 100 \\
\hline $\begin{array}{l}\text { Financial } \\
\text { statement } \\
\text { are } \\
\text { submitted } \\
\text { for } \\
\text { examination } \\
\text { promptly }\end{array}$ & 18 & 19 & 43 & 45 & - & - & 7 & 7 & 28 & 29 & 96 & 100 \\
\hline $\begin{array}{l}\text { Auditor } \\
\text { general was } \\
\text { able to } \\
\text { acquire } \\
\text { information } \\
\text { necessary } \\
\text { for audit } \\
\text { work }\end{array}$ & 27 & 28 & 10 & 10 & 1 & 1 & 21 & 22 & 37 & 39 & 96 & 100 \\
\hline
\end{tabular}

4.2.2 The Extent to which Reporting Independence is Achieved in the Public Sector Organizations.

Reporting independence as perceived by the independence regulations in the European Union (2009), protects the auditors' ability to choose to reveal to the public and information they believe should be disclosed. In that regard, a survey was carried out to investigate the extent to which reporting independence was achieved in the Nigeria public sector organizations. $69 \%$ of the respondents agreed and strongly agreed that auditor general was able to report directly to the legislature without any external interference with the editing of their reports. This implies that reporting independence has been achieved in the public sector organizations 
in Nigeria. In like manner, there were public account committees established by the legislature and the substantial development in the public sector auditing in the last five years was that the public account committees were able to consider and review the annual financial statement of the government as prepared by the accountant generals and the report of the auditor general. Furthermore, it was observed that in the sampled states auditor general was able to appoint his staffs up to the grade level six as expressed by $83 \%$ of the respondents while senior and professional staffs were recruited and promoted by the civil service commission. It would have been more appropriate if auditor general was able to recruit staff at the other levels so that professional competency needed for the job can be a major yardstick. Surprisingly, auditor general office appeared to be distinctly separated from the ministry of finance with $25 \%$ and $53 \%$ strongly agreed and agreed respectively. The high scoring of this aspect of the reporting independence will assist in preventing undue restriction and interference with audit assignment

Table 3. The extent to which reporting independence was achieved in the public sector organizations

\begin{tabular}{|c|c|c|c|c|c|c|c|c|c|c|c|c|}
\hline & \multicolumn{2}{|l|}{$\begin{array}{l}\text { Strongly } \\
\text { Agreed }\end{array}$} & \multicolumn{2}{|l|}{ Agreed } & \multicolumn{2}{|l|}{ Indifferent } & \multicolumn{2}{|l|}{ Disagreed } & \multicolumn{2}{|l|}{$\begin{array}{l}\text { Strongly } \\
\text { Disagreed }\end{array}$} & \multicolumn{2}{|l|}{ Total } \\
\hline & Frequency & $\%$ & Frequency & $\%$ & Frequency & $\%$ & Frequency & $\%$ & Frequency & $\%$ & Frequency & $\%$ \\
\hline $\begin{array}{l}\text { Auditor } \\
\text { general was } \\
\text { able to report } \\
\text { directly to } \\
\text { the } \\
\text { legislature. }\end{array}$ & 45 & 47 & 21 & 22 & 3 & 3 & 22 & 23 & 5 & 5 & 96 & 100 \\
\hline $\begin{array}{l}\text { There is a } \\
\text { public } \\
\text { account } \\
\text { committee at } \\
\text { each state. }\end{array}$ & 48 & 50 & 26 & 27 & - & - & 14 & 15 & 8 & 8 & 96 & 100 \\
\hline $\begin{array}{lr}\text { Auditor } & \\
\text { general was } \\
\text { able } & \text { to } \\
\text { appoint } & \text { his } \\
\text { staff. } & \end{array}$ & 48 & 50 & 32 & 33 & - & - & 2 & 2 & 14 & 15 & 96 & 100 \\
\hline $\begin{array}{l}\text { Auditor } \\
\text { general } \\
\text { office was } \\
\text { not an } \\
\text { extension of } \\
\text { ministry of } \\
\text { finance }\end{array}$ & 24 & 25 & 51 & 53 & 3 & 3 & 18 & 19 & - & - & 96 & 100 \\
\hline
\end{tabular}




\section{$\Lambda$ Macrothink}

4.2.3 The Extent to Which Financial Independence is Achieved in the Public Sector Organizations

The empirical results as presented in table 4 revealed that financial independence has been achieved in the public sector organizations in Nigeria. This was based on the over whelming response rate of $89 \%$ affirming that auditor general budget was approved by the legislature in the same way as the annual budget for each ministry. Furthermore, as freely expressed by the respondents and supported by sec 125 of 1999 constitution, the salary and other remuneration of the auditor general was decided directly by the legislature. In the same vain auditor generals in the sample states were able to attend annual conference organized by his professional bodies.

\begin{tabular}{|c|c|c|c|c|c|c|c|c|c|c|c|c|}
\hline & \multicolumn{2}{|c|}{ Strongly Agreed } & \multicolumn{2}{|l|}{ Agreed } & \multicolumn{2}{|l|}{ Indifferent } & \multicolumn{2}{|l|}{ Disagreed } & \multicolumn{2}{|l|}{$\begin{array}{l}\text { Strongly } \\
\text { Disagreed }\end{array}$} & \multicolumn{2}{|l|}{ Total } \\
\hline & Frequency & $\%$ & Frequency & $\%$ & Frequency & $\%$ & Frequency & $\%$ & Frequency & $\%$ & Frequency & $\%$ \\
\hline $\begin{array}{l}\text { There is a } \\
\text { separate budget } \\
\text { for the auditor } \\
\text { general's office }\end{array}$ & 59 & 62 & 26 & 27 & 4 & 4 & 7 & 7 & - & - & 96 & 100 \\
\hline $\begin{array}{l}\text { Auditor } \\
\text { general's } \\
\text { budget was } \\
\text { determined by } \\
\text { the legislature }\end{array}$ & 31 & 32 & 48 & 50 & 2 & 2 & 15 & 16 & - & - & 96 & 100 \\
\hline $\begin{array}{l}\text { Auditor general } \\
\text { was entitle to } \\
\text { annual salary } \\
\text { increase and } \\
\text { fringe benefits }\end{array}$ & 36 & 38 & 54 & 56 & - & - & - & - & 6 & 6 & 96 & 100 \\
\hline $\begin{array}{l}\text { Auditor general } \\
\text { was able to } \\
\text { appoint the } \\
\text { suppliers of } \\
\text { services }\end{array}$ & 58 & 61 & 4 & 4 & - & - & 32 & 33 & 2 & 2 & 96 & 100 \\
\hline
\end{tabular}

\subsection{Inferential Results}

To determine the effect of investigative independence, reporting independence, financial independence on the quality of audit assignment in the public sector organizations multiple regression analysis was carried out. With $\mathrm{R}$ square 0.62 , the combine effect of investigative independence, reporting independence, and financial independence are significant in determining the quality of audit assignment done by the public sector auditors. This implies that $62 \%$ of variation in the quality of audit work in the public sector organizations were caused by the independent variables (investigative independence, reporting independence, 
and financial independence) while the remaining $38 \%$ were caused by the other variables not captured in this study.

Consequently, the relationship between audit job and investigative independence was to be positive and significant. This was supported by the coefficient of 0.001 and $t-$ statistics of 3.333. This implies that the likelihood of quality audit job is greater in the public sector where investigative independence is achieved.

Similarly, the relationship between audit job and reporting independence was significantly positive at $1 \%$ level of significance (coefficient $=0.037, \mathrm{t}-$ statistic $=12.333$ ) suggesting that auditor are able to do their job ethically where they are able to report their finding to the appropriate authority.

In like manner, and as suggested by other research studies such as Agambi and Adekunmi, (2002), and Mothaz, (2008) among others, the relationship between financial independence and audit assignment is very significant and positive. More importantly, the coefficient was 0.079 while the t-statistic was 4.638 , fallen on the rejection region of the null hypothesis using 2 tail statistic at 5\% level of significance. Therefore, our alternative hypothesis which predicts a relationship between audit job and financial independence was not rejected.

Table 5. Model Summary

\begin{tabular}{ll}
\hline Indicators & \\
Coefficients & \\
R-Square & 0.623426 \\
Adjusted R-Square & 0.611147 \\
Standard Error & 0.545653 \\
Observation & 96 \\
\hline
\end{tabular}

Table 6. Analysis of Variance

\begin{tabular}{llcccc}
\hline Df & SS & \multicolumn{2}{c}{ MS } & Sig. \\
\hline Regression & 3 & 45.34778 & 15.11593 & 50.76939 & $1.89 \mathrm{E}-19$ \\
Residual & 92 & 27.39181 & 0.297737 & & \\
Total & 95 & 72.73958 & & & \\
\hline
\end{tabular}

Table 7. Regression Coefficient

\begin{tabular}{lcccc}
\hline Variables & Beta & Std. Error & T- Statistic & Sig. \\
Constant & 0.335 & 0.0216 & 1.552 & 0.000 \\
Investigative Independence & 0.001 & 0.0003 & 3.333 & 0.010 \\
Reporting Independence & 0.037 & 0.003 & 12.333 & 0.000 \\
Financial Independence & 0.079 & 0.017 & 4.638 & 0.000 \\
\hline
\end{tabular}

\section{Conclusion}

Audit independence has always been considered a crucial attribute for auditors. An auditor both in the private and public sector organization is saddled with the responsibility of ascertaining the true and fair view of the financial position of the organization being audited. 


\section{$\triangle$ Macrothink}

However, the extent to which this will be achieved depends on the level of independence maintained by the auditor. In the light of that, this study provides empirical analysis of the audit independence maintained by the public sector auditors' in Nigeria. The primary objective guiding this study was to investigating the extent to which public sector audit independence is achieved and how this independence is achieved in the Nigeria public sector organizations while the specific objectives were to investigate the extent to which investigative independence is achieved in the public sector organizations, to investigate the extent to which reporting independence is achieved in the public sector organizations, to investigate the extent to which financial independence is achieved in the public sector organizations, and also to determine the effect of investigative independence, reporting independence, financial independence on the quality of audit assignment in the public sector organizations. In order to achieve the objectives of the study, a survey research design was adopted in which primary data were collected with the aid of a well-structured questionnaire to the randomly selected 105 staff of the auditor general office in the sampled states. Similarly, the study adopted descriptive and inferential statistics for data analysis with the aid of Stata-64. The results of descriptive analysis revealed that both investigative independence, reporting independence and financial independence has relatively been achieved by the auditors in the public sector organizations in Nigeria. It was also discovered that auditor's independence was significantly influenced by

\section{References}

Aderibigbe, P. (2005). Auditor's Independence and Corporate Fraud. Journal of Social Sciences, 10(2), 135-139.

Agambi \& Adekunmi. (2002). The effect of Partner Compensation Schemes and Generally Accepted Accounting Principles on Auditor Partner Judgmen. Auditing, A Journal of Practice and Theory, 13(1), $56-68$.

Baker, C. R. (2005). The Varying Concept of Auditor Independence, Shifting with the Prevailing Environment; retrieved from http,/www.nysscpa.org, on 8/10/2009

DeAngelo, L. (1981). Auditor size and Auditor quality, Journal of Accounting and Economics, 3(12), 183 - 199. http://dx.doi.org/10.1016/0165-4101(81)90002-1

Dictionary of International Accounting Terms (2001).Financial World Publishing, Spain.

Doyle, J. (2005). The Role of the Auditor General, Auditing in the Public Interest Journal, $12(2), 254-266$

Dunn, J. (1996). Auditing Theory and Practice.2nd ed. Prentice Hall.

Gray, I. \& Manson, S. (2000). The Audit Process, Principles, Practice and Cases, Thomson, $2^{\text {nd }}$ ed. United States.

Hayes, R., Dassen, R., Schilder, A., \& Wallage P. (2005). Principles of Auditing, An Introduction to International Standards on Auditing. Prentice Hall, 2nd ed. Millan. 
ICAEW. (2009). Auditor Independence, retrieved from http,//www.icaew.com, on $08 / 11 / 2009$.

John, D. (2005). TheRole of the Auditor General, Auditing in the Public Interest Journal, $12(2), 254-266$

Louwers, J. T., Ramsay, J. R., Sinason, H. D., \&Strawser, R. J. (2007). Auditing and Assurance Services. Journal of Accounting and Economics, 14(2) 344-366

Mautz, R.K. and Sharaf, H.A. (1961). The Philosophy of Auditing. American Accounting Association, Sarasota Springs, 4th ed, $111-112$.

McGrath S., Siegel, A., Dunfee, T. W., Glazer, A. S., \& Jaenicke, H. R. (2001). A Framework for Auditor Independence. Journal of Accountancy, 1(4), 1-4.

Mothaz. (2008). Auditor Independence as a Unique Equilibrium Response. Journal of Accounting, Auditing and Finance, 10(1), 81-102.

Muhamad, Z., \& Karbhari, Y. (2006). Auditor Reputation and Auditor Independence in an Emerging Market, retrieved from http//www.papers.ssrn.com, on 12/11/2009.

Nashuwa, G. (2005). The role of audit committees in the public sector. Certified Public Accountant Journal, 17(2), 18-26

Nelson, M., Elliot, J. \& Tarpley, R. (2002). Evidence from auditors about mangers' and auditors' earning management decisions. The Accounting Review, 77(Supplement), 175-202. http://dx.doi.org/10.2308/accr.2002.77.s-1.175

Oladipupo, A. O., \& Izedonmi F. I. (2013). Propensity of unqualified audit reports and auditor's independence in Nigeria. African research review, 7(3), 34-46

Paul A., \& Walker D.Z. (2009). Audit Independence and Non-Audit Services- A Comparative Study in Differing British and French Perspectives, Serbian Journal of Management, 3(2), 21 - 22.

Smith Report. (2003). Reviewing Auditor Independence, retrieved from http,//www.books.google.com, on 15/11/09.

Tairu, K.O. (2006). The Future of Accounting, Part III, Reliability and Auditor Independence, The Accounting Horizon, 10(1), 31-41.

Trompeter, G. (1994). - The effect of Partner Compensation Schemes and Generally Accepted Accounting Principles on Auditor Partner Judgment. Auditing, A Journal of Practice and Theory, 13(1), 56-68. 